\title{
RFID Based Toll Deduction System
}

\author{
Asif Ali Laghari, M. Sulleman Memon and Agha Sheraz Pathan
}

Department of Computer Systems \& Information Technology, Quaid e Awam University of Engineering, Science and Technology, Nawabshah, Sindh, PAKISTAN asifalilaghari@hotmail.com, sullemanhalai@yahoo.com

\begin{abstract}
In this research paper we examine RFID based toll deduction system and how to make more efficient and perfect. The vehicle will be equipped with a radio frequency (RF) tag which will detect RF Reader located in on toll plaza. The amount will then automatically deduct from the bank account. This research paper can be considered scalable to implement in motor vehicles used today.
\end{abstract}

Index Terms-FRID, Deduction, Walking Plant System, Tag

\section{Introduction}

Million of drivers/consumer passes through toll booths paying toll tax. In past toll payment system was manually and drivers are using manual system using coin or cash by hand to cross the toll plaza gate. Manual process is too much time consuming and drivers have to wait in row for long time for crossing the toll plaza. In waiting time oil of vehicle is also consuming. Now days this manual toll deduction system is changed to automated system. Where driver no wait for pay cash or get token to cross the toll plaza. This automatic system used [6] the technology of RFID. This new automated system works very fast with best results. This system depends on four devices.

- Tag: Transponder

- RF Reader: Antenna

- Traffic controller system:

Traffic controller system is computer system which manages the traffic in single row or line by using traffic signals.

- Central Server:

Central server stores the data which comes from different toll plaza. A local computer of every toll plaza is connected to central server through Internet.

Consumer/drivers have to purchase and deposit money for tag. The tag has necessary information of vehicle and bank account deposit of consumer/driver. Tag can be installed on the first front number plate of vehicle. There are two types of tag, Active tag and passive tag. The concept is shown in Figure 1. 


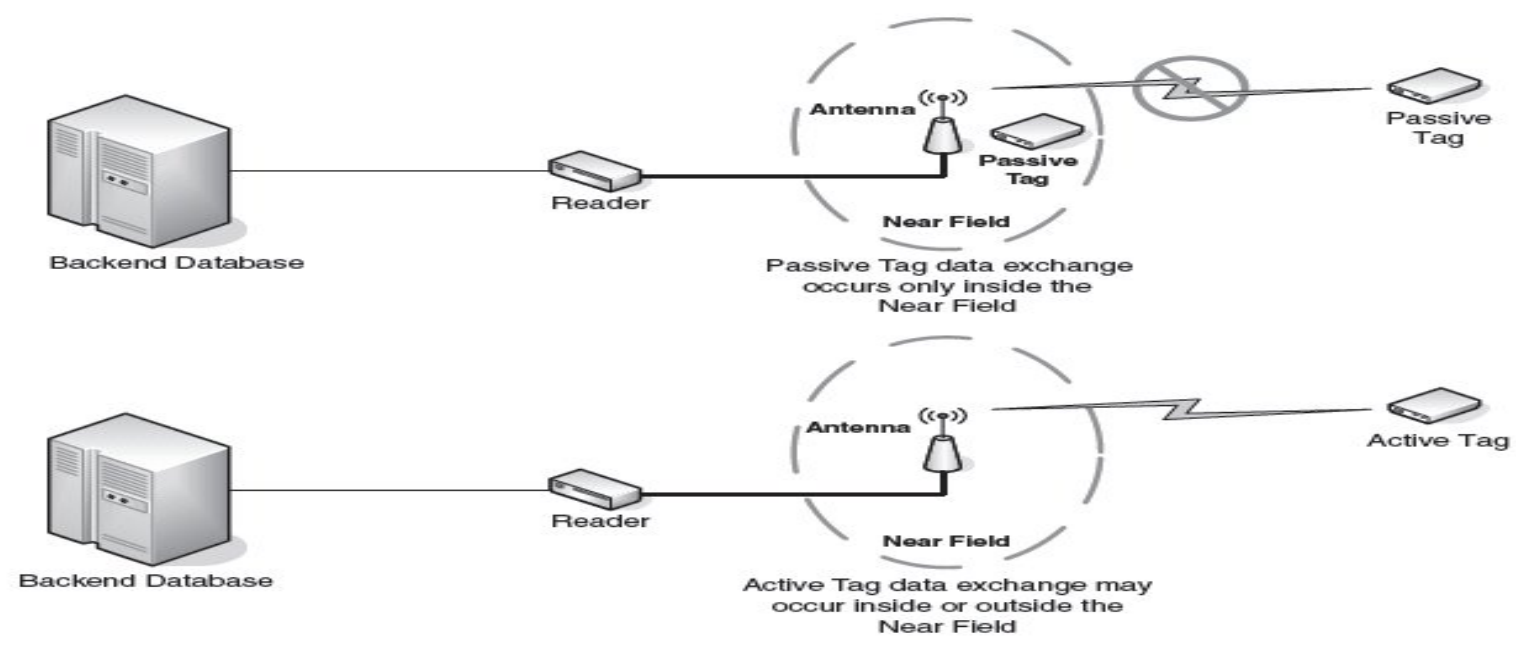

Fig 1: Active and Passive tags

\begin{tabular}{|l|l|l|l|l|l|l|}
\hline Type of Tag & $\begin{array}{l}\text { EPC } \\
\text { Class }\end{array}$ & $\begin{array}{l}\text { Memory } \\
\text { Type }\end{array}$ & $\begin{array}{l}\text { Radio } \\
\text { Frequencies } \\
\text { Used }\end{array}$ & $\begin{array}{l}\text { Word } \\
\text { Length, } \\
\text { Bits }\end{array}$ & $\begin{array}{l}\text { Power } \\
\text { Source }\end{array}$ & $\begin{array}{l}\text { Reading } \\
\text { Distance, } \\
\text { Meters }\end{array}$ \\
\hline \hline RFID passive & 0 & ROM & $\begin{array}{l}138 \mathrm{KHz} \\
13.85 \mathrm{MHz}\end{array}$ & 64 & $\begin{array}{l}\text { Reader } \\
\text { EMF }\end{array}$ & $0.04-3$ \\
\hline RFID active & 4 & ROM & $13.85 \mathrm{MHz}$ & 64 & Battery & $3-10$ \\
\hline $\begin{array}{l}\text { RFID passive } \\
\text { programmable }\end{array}$ & 1 & EEPROM & $\begin{array}{l}138 \mathrm{KHz} \\
13.85 \mathrm{MHz}\end{array}$ & 96,128 & $\begin{array}{l}\text { Reader } \\
\text { EMF }\end{array}$ & $0.04-3$ \\
\hline $\begin{array}{l}\text { RFID active } \\
\text { programmable }\end{array}$ & $2,3,4$ & EEPROM & $\begin{array}{l}138 \mathrm{KHz} \\
13.85 \mathrm{MHz}\end{array}$ & $>128$ & Battery & $3-10$ \\
\hline Data tag & $2,3,4$ & $\begin{array}{l}\text { CMOS RAM } \\
\text { Flash RAM }\end{array}$ & $\begin{array}{l}13.85 \mathrm{MHz} \\
985 \mathrm{MHz}(\mathrm{UHF})\end{array}$ & $>128$ & Battery & $3-10$ \\
\hline RF location & - & $\begin{array}{l}\text { EEPROM or } \\
\text { CMOS RAM }\end{array}$ & $\begin{array}{l}303 \mathrm{MHz}, 2.4 / 5.8 \\
\text { GHz, UWB }\end{array}$ & 64 & Battery & $1-100$ \\
\hline
\end{tabular}


Active tag has battery and generates RF (Radio Frequency) signals. Passive [8 10] tag activates from the Readers signals and sends information back to reader. The tag has [5] microprocessor which received signals and send signals of $900 \mathrm{MHz}$ bands. Different types and ranges of tags are given above in Table 1.

Reader/ antenna are installed [6] on the toll plaza on every single row where vehicle are passed. The antenna generates signals to receive data from tag. The communication [8 9] area of antenna is 5 to 12 feet in every direction. Antenna receive information [6] from vehicle tag and send to central server which contains the database of all consumer which use service of RFID based toll deduction system. Transaction of toll tax is easily done from the owner of tag.

\section{Related Work}

India [2] National ID Card Program, In September 2010 India is begun issuing RFID and biometric enhanced ID cards to citizens. Railway Safety: Hochbahn Company [2] daily serves for 500,000 people in Hamburg Germany; they implement RFID for passenger safety. In Malaysia [3] RFID tags are used in Library by replacing EPC Global Gen Standard. In Netherlands RFID [4] was implemented in Walking
Plant System (WPS), to keep watch growth progress of plants. RFID also used in education system for attendance [1] system of students in universities and colleges. Figure 2 gives a case study example of monitoring Student Attendance System with Time.

RFID replaces the bar Codes in different products and now RFID is used and now days RFID is most popular technology which is used in [13] Supply chain.

\section{Our Proposal}

In this paper our focus on automatic toll deduction system with more features for consumer/driver convenience and time saving. The vehicle will be equipped with Radio Frequency (RF) tag, which will be detected by [12] RF Reader, located on toll plaza. The amount will be automatically deducted from the bank account. A camera will installed on the toll plaza, camera will take picture of number plate of vehicle which is used for catch the theft vehicle. Speed of vehicle [5] can be controlled using RFID we control the speed of vehicle up to $5 \mathrm{~km} / \mathrm{h}$ from at the time of passing from the toll plaza. 


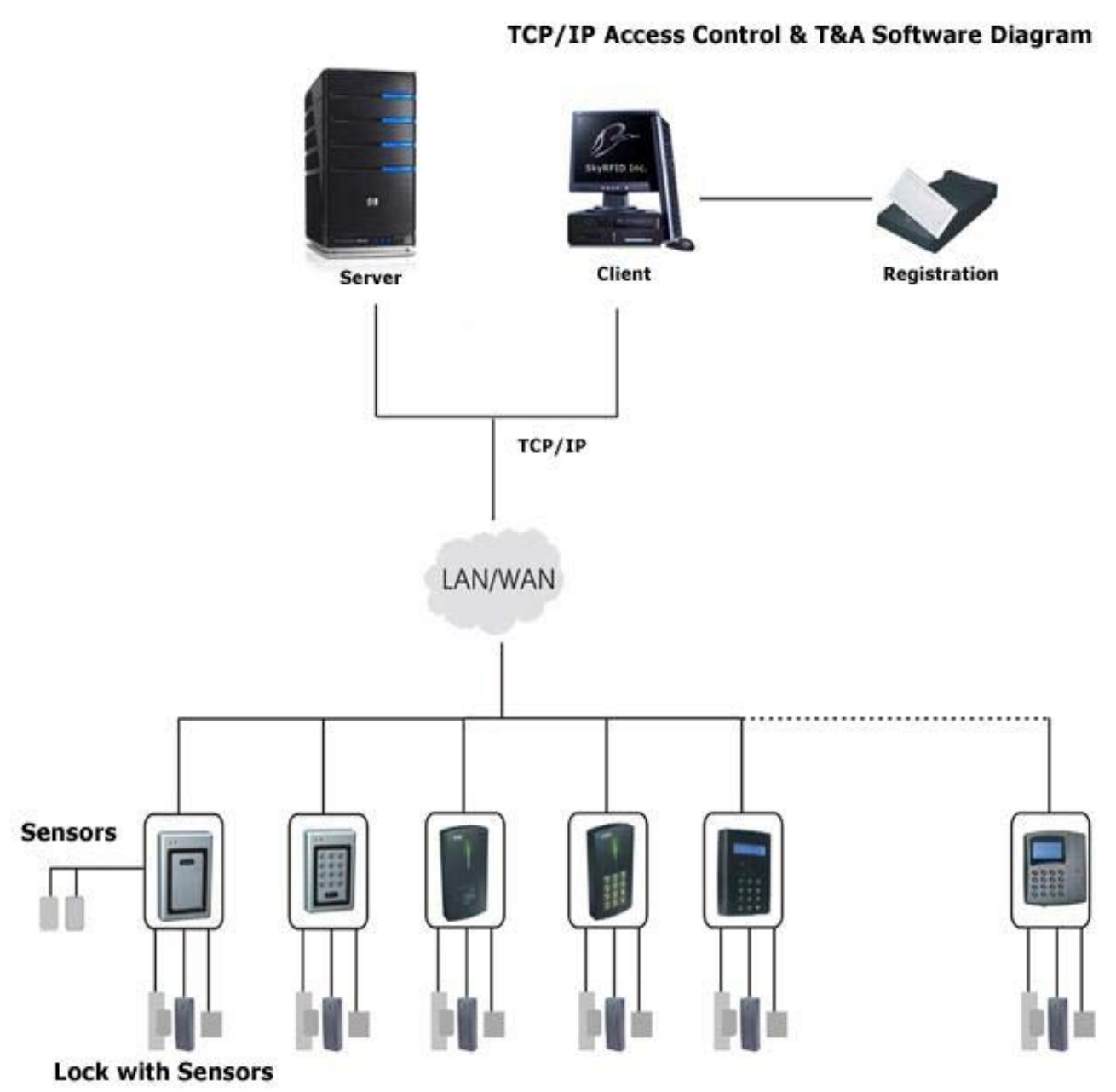

Fig 2: Student Attendance System with Time

\section{Tolls}

Tag (Transponder), Lane Controller, Middleware Software, Central Server and Camera.

\subsection{Design}

RFID tag can be installed with number plate; Mount your exterior license plate tag at the top of your front license plate with has faced upward readable position. Figure 3 gives a phenomenal design approach for the research purpose and concept.

The Reader (Antenna) or interrogator receives [11] data from the tag which placed on vehicle, reader can have an integrated antenna or the antenna can be separate. Reader is placed on the middle of toll deduction gate and it is connected to Central Server (backend database).
Middleware software: Middleware [5 6] software connects reader and the Central server and the data coming from the tags stored in backend database. Middleware sits in the middle of the data flow of information between the reader and backend database of Central server. It is connected to reader which placed out side on the gate of toll plaza. Central server is also connected to LAN (local area network). All computer system of LAN is connected to a central database via a WAN (wide area network). The whole record of toll deduction will be stored at the Central server and monthly transaction will be sent to the consumer from the Central server. 


\subsection{Account Information}

For purchase tags any individual can give application and vehicle of his/her is registered in database and account will be open in bank. All information of bank account and regard to vehicle is stored in tag. Every time vehicle passed from the toll plaza reader fetch information from the tag and toll tax is deducted from bank account. Toll tax is deducted as the type of vehicle is passed means different rates of toll tax for different type of vehicles like cars, vans, trucks, motorcycles etc.

To access or update account information the website, automated phone system or through a customer service representative, you are required to provide your account number and [5] PIN number. Your account number is included on your statement. Consumer will receive a statement of accounts on the monthly basis. Account statement contain record of total balance, date of open of account, every transaction, date, time location and payment details and also remaining credit of your account. If consumer doesn't deposit credit to his/her account to long time and short credit is remain then he will receive a message of short credit by email or phone alert.

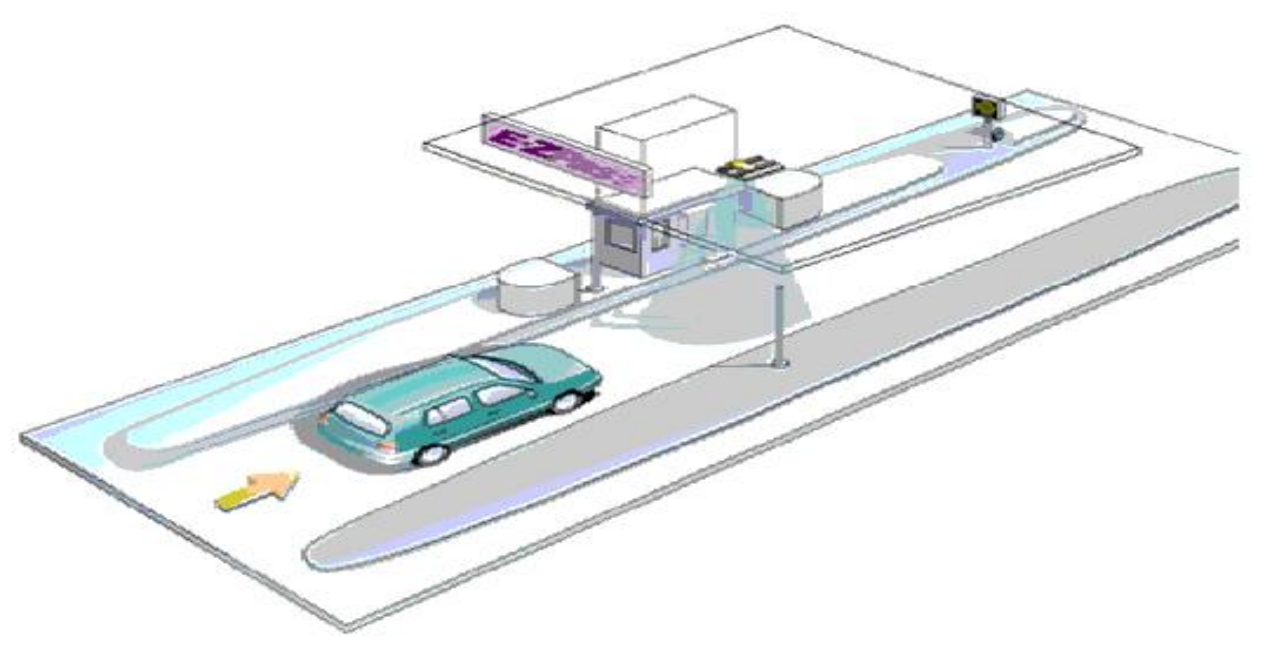

Fig 3: Traffic Controller

\section{Working}

In RFID based toll deduction system a vehicle arrive in toll plaza range antenna send signals to tag and activate the tag, tag send back information to antenna. As data receive to antenna [9] it sends to central server database. Server checks information of account consumer/driver, if account have credit more then required tax then tax is subtract from account and driver will pass the toll plaza. A transaction message also sends to consumer/driver that how much tax is paid and remaining balance of account. Passing of vehicle and transaction of tax is completed within short time.

The central server stores all information of transaction, which contain location of toll plaza, date, time and total amount payment of tax. If the credit of account is low then system generates 


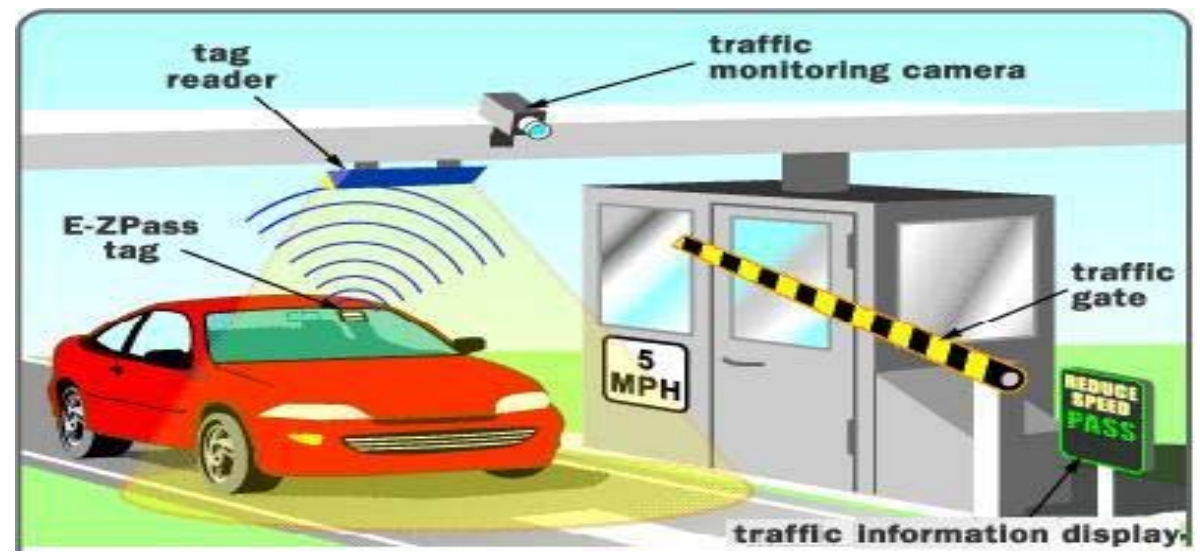

Fig 4: complete working of toll deduction system

indication for low balance. The speed limit for passing from toll plaza is not constant on every toll plaza because some companies are set speed limit 86 kilometers per hour (5 mph) and some companies set speed limit to 48 kilometers per hour or low 8 kilometers per hour. Video cameras are installed on the toll plaza for the observation that any consumer can not pass without having tag in vehicle. Any consumer/driver pass from toll plaza then camera capture picture of number plate and send abuse notice to the owner of vehicle through the email. Figure 4 highlights the above discussed procedures with specific tag, camera and gate positions.

\section{Vehicle Speed Control through RFID}

RFID can also be implemented in vehicles to control the speed of the car. Such system can be named as automatic vehicle speed control system. The vehicle will be equipped with a radio frequency (RF) reader which will detect RF transmitters located on the speed limit signs posted on the side of road.

The vehicle will then automatically adjust is speed so as to obey the speed limit for that particular stretch of road. This project can be considered scalable to implement in motor vehicles used today, an overview of system can be seen in Figure 5.

\subsection{Reducing Car Theft}

Copyright (C) 2012 MECS
RFID can provide an effective deterrent against car [5] theft. A solution for this type I characterized by the following:

Attaching a tag to vehicle to be monitored for theft. Reading the tag ID at the vulnerable points (for example, at exit points, during starting of the ignition of an automobile, and so on).

An application for this is automotive anti-theft immobilization. In this commercially deployed solution, an embedded reader located inside the car (for example, in the steering wheel) becomes activated when a driver turns the ignition key. This reader then attempts to read the valid unique code from a tag in its vicinity.

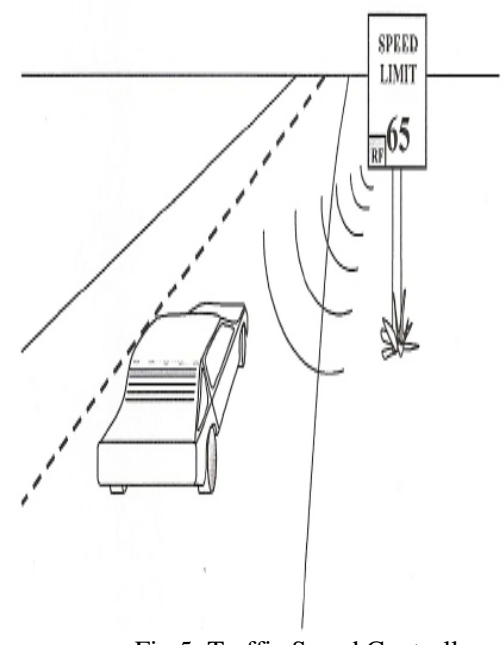

Fig 5: Traffic Speed Controller

\section{Comparison with Previous Mechanisms}

So many new projects is done through the using of RFID and so many manual systems are now 
automated by using the technology of RFID. In previous work of RFID is that make manual system to automate for time saving and keep record up to date. For example Student attendance system, students attend the class then their attendance is counted in database and their timing of arrival and leaving. In previous toll deduction system only simple way tax is deducted from the account. But further implementation or scaling of project of toll deduction system is stop the anti theft of vehicle and control the speed of vehicle by using RFID technology. Also keep stop violation of rules if any vehicle did not have tag then camera take snapshot of vehicle and send alert to next station of toll plaza to catch the vehicle.

\section{Conclusion}

The development of RFID based toll deduction system is proved that RFID technology have good results in implementing in different applications but the standard company have develop the framework of applications. In this toll deduction system RFID is used permitted frequency bands by using high power levels, then system will be successful. The companies which have permissions from the authorities because tag is use the bank account and registration numbers of vehicles. For this application passive tag are better then to active tag because of low cost and also radio signals environmental factors. For the future work RFID speed controlled system vehicle can be save from the accident due to high speed. Some works will be done auto steering system of vehicle which can be controlled by using RFID technology installed on the complete track. This will be beneficial if bus driver have serious problem of heart attack or other disease suddenly then control transfer to automatic RFID communication system. Some work must be on RFID communication range between the Reader/antenna and tag is limited in to few meters it will be extend to long range.

\section{Acknowledgment}

Authors are thankful to Director Post graduate and administration of Quaid e Awam UEST, Nawabshah, PAKISTAN to provide the lab facilities to conduct this piece of research.

\section{References}

[1] http://www.psfk.com/2010/05/using-rfids-to-takestudent-attendance.html

[2] http://rfid.thingmagic.com/rfidblog/?Tag=Railway+Management

[3] http://www.upmraflatac.com/northamerica/eng/ne ws/presscenter/2009/43_72708.asp

[4] http://www.b-eye-network.com/view/5672

[5] Frank Thornton, Brad Haines \& Anand M. Das "RFID Security" Syngress publishing, Canada, April, 2006.

[6] Himanshu Bhatt, Bill Glover "RFID Essentials" publisher: O’Reilly. January 2006

[7] Sandip Lahiri, "RFID Sourcebook" Publisher: Prentice Hall PTR. August 31, 2005, ISBN: 0-13185137-3.

[8] OTA Training, Eva Zeisel, Robert Sabella. "RFID+Exam Gram" Publisher: Que, may 16, 2006

[9] Patrick J. Sweeney II “RFID for Dummies” Wiley Publishing, Inc. Indiana ISBN: 0-7645-7910-X, 2005.

[10] Yan Zhang, Paris Kitsos, “security in RFID and Sensor Network (wireless Networks and Mobile Communication)” Auerbach Publications, 2009. ISBN: 1420068393.

[11] S Jaya Krishna, “ RFID: applications and cases” Publisher: Icfai University press Hyderabad, India. 2010.

[12] Giuliano Benelli, Stefano Parrino And Alessandro Pozzebon "RFID Applications for Sanitary Environments” Publisher: InTech. February 2010.

[13] Pedro M. Reyes "RFID in the Supply Chain" Publisher: McGraw-Hill Professional, 1 edition January 2011. ISBN-10: 0071634975.

Asif Ali Laghari, Graduate Student MSIT , Department of Information Technology, Quaid e Awam University of Engineering, Science and Technology, Nawabshah, Sindh, PAKISTAN

M. Sulleman Memon and Agha Sheraz Pathan, Department of Computer Systems Engineering, Quaid e Awam University of Engineering, Science and Technology, Nawabshah, Sindh, PAKISTAN 